\title{
A MODEL PREDICTIVE APPROACH TO BLAST FURNACE OPERATIONAL MANAGEMENT AUTOMATION
}

\author{
L.S. Kazarinov' ${ }^{1}$ kazarinovls@susu.ru, \\ D.A. Shnayder', shnaiderda@susu.ru, \\ T.A. Barbasova ${ }^{1}$, barbasovata@susu.ru, \\ A.A. Basalaev', basalaevaa@susu.ru, \\ o.V. Kolesnikova1, kolesnikovaov@susu.ru, \\ A.V. Lipatnikov², llipass@mail.ru \\ ${ }^{1}$ South Ural State University, Chelyabinsk, Russian Federation, \\ 2 OJSC "Magnitogorsk Iron and Steel Works", Magnitogorsk, Russian Federation
}

Blast furnace operational management automation using modelling and real-time predictive solutions for the object control are considered. Main features of the proposed control are: using of an operational data mining software to identify effective clusters of the furnace regime parameters values; real-time software for identification of the furnace cohesion zone parameters for the operational management correction; dynamics forecasting of the furnace thermal state indicators when charge load and blast parameters change.

Usage of the software permits to achieve effective values of the furnace regime parameters with high productivity and reduced coke consumption. It is effective in conditions of the significant charge parameters changes, due to using of source materials from different suppliers. Therewith, forecasting of parameters dynamics allows supervisor to stabilize the blast furnace process in the effective regime.

The system is based a joint development of the South Ural State University (National Research University), "Polytech-Automatica" Research \& Production Ltd. (Chelyabinsk) and "AKOMM" Ltd. (Moscow).

Keywords: blast furnace process, model predictive control.

\section{Introduction}

A promising work direction to improving the efficiency of blast-furnace processes control is application of methods, based on modeling and predictive solutions.

In general, the use of blast furnace models has a great history and a large number of sources on this topic is available.

It is necessary here to note the works of national authors I. Tovarovskiy, A. Gotliba, G. Efimenko, A. Gimmelfarb, A. Pokhvisnev, O. Onorine, N. Spirin, A. Ramma, A. Dmitriev [1-26]. The works of V. Parshakov [12-15], devoted to study of influence of the cohesion zone parameters on the blast furnace process efficiency, deserve special attention. It is necessary to note among foreign authors the works of J. Kule, M. Sasaki, K. Ono, A. Suzuki, J.M. Burgess, D.R. Jenkins, K.L. Hockings, S.A. Kumar, N. Suresh, C.P. Jeffreson, M. Gobetto [27-41].

However, as far as the blast furnace process is quite sophisticated and its parameters are not fully observable the specified problem is not completely solved now and studies on the topic are still conducted.

The main features of the proposed approach are:

- usage of the operational data mining software to identify effective regions of the blast furnace technical parameters values, providing productivity increase and coke consumption reduction;

- real-time software for identification of the furnace cohesion zone current parameters for the operational management correction;

- forecasting of the blast furnace thermal state indicators dynamics when the blast parameters or charge load change. 


\section{The blast furnace control model general structure}

The main difficulties preventing the achievement of high technical and economic efficiency levels are:

1) partial observability and controllability of processes;

2) the need for the processes stabilization in extreme boundary conditions;

3 ) incomplete knowledge about the current process state due to its complexity.

To overcome the above difficulties an advanced methodology of model predictive management is now developed. The peculiarity of this methodology comes from usage of controlled object modelling software with permanent on-line updating based on constant parameters identification by the real operational data for the observability and controllability of processes.

Therewith, each managing step solves the problem of control action on technical and economic indicators optimization.

The general structure of the model-predicative management is shown on Fig. 1.

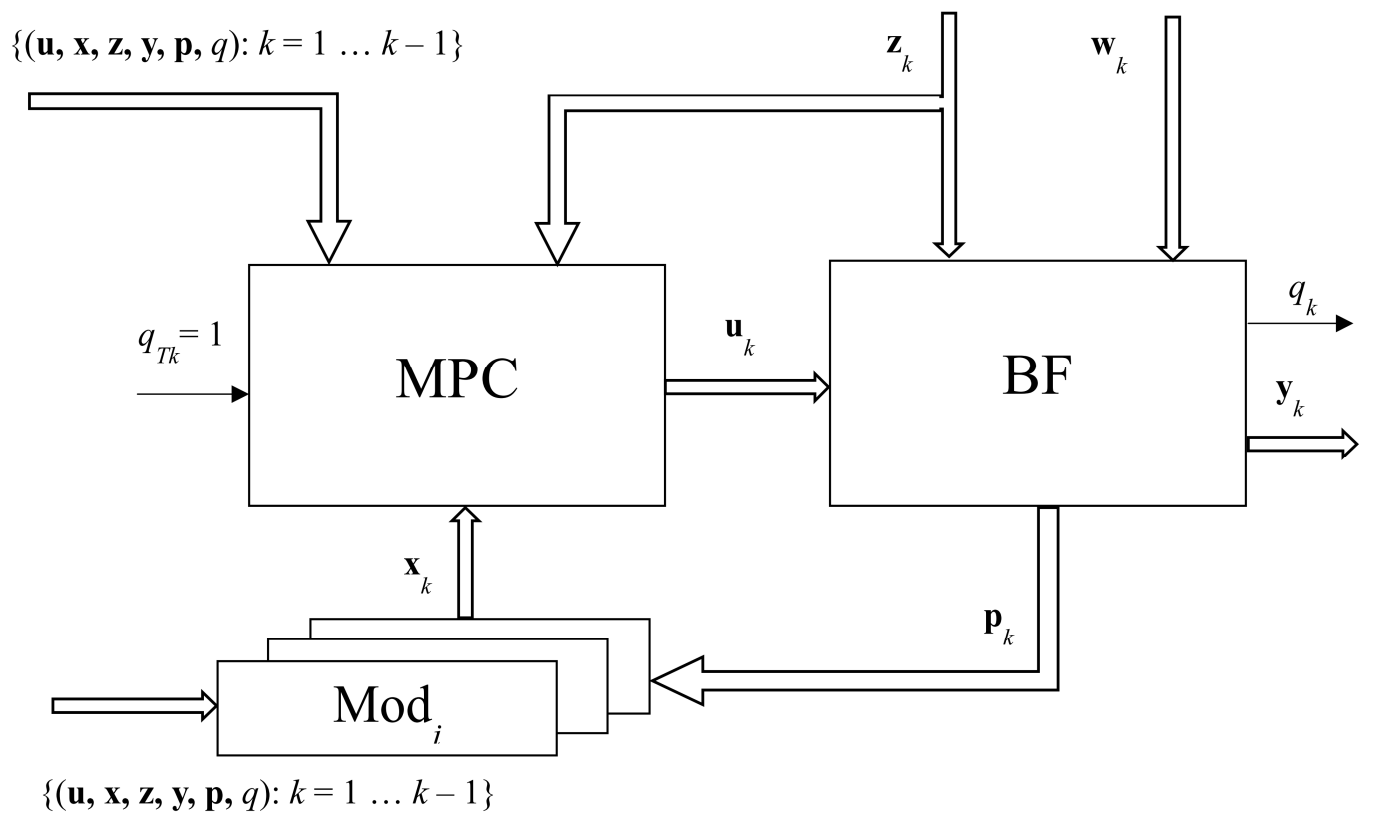

Fig. 1

Here in $\mathbf{u}_{k}-$ the controlled parameters of the blast furnace process (BFp); $\mathbf{z}_{k}-$ measured uncontrolled parameters of the BFp; $\mathbf{w}_{k}$ - unmeasured disturbance factors of the BFp; $q_{k}$ - the blast furnace process efficiency indicator:

$q_{k}=\left\{\begin{array}{l}1, \text { if BPf is satisfied with determined performance efficiency; } \\ 0, \text { otherwise, }\end{array}\right.$

$\mathbf{y}_{k}$ - the output measured parameters of the BFp; $\mathbf{x}_{k}$ - the blast furnace process state vector, for a satisfactory prediction of BFp characteristics; $\mathbf{p}_{k}-$ the measured parameters of the blast furnace process used to estimate its state vector; $\{(\mathbf{u}, \mathbf{x}, \mathbf{z}, \mathbf{y}, \mathbf{p}, q): k=1 \ldots k-1\}$ - previous BF melting parameters statistics; $\operatorname{Mod}_{i}-$ the $i$-th model representation of the BFp, which provides state vector estimation according to technological instructions; MPC - the program of the model-predictive management calculation; $k$ - the current melting index.

One BFp model representation for the state vector evaluation is the "AKOMM" Ltd. "Cohesion" system, which provides a quantitative assessment of the melting zone parameters.

\section{Effective regions of the operating parameters clustering}

The effective operating parameters regions are determined by the blast furnace target indicators settings, such as productivity, coke consumption, theoretical combustion temperature, furnace thermal state indicators (the cast iron silicon content, titanium module, blast-furnace gas utilization, etc.) 


\section{Управление в технических системах}

For instance, Fig. 2 represents effective region detection, based on the target function:

$$
e_{k}=\alpha_{n} n_{i r}+\alpha_{c} b_{c}^{-1}, \alpha_{n}, \alpha_{c} \geq 0, \alpha_{n}+\alpha_{c}=1
$$

where $n_{i r}$-relative cast iron perfomance; $b_{c}$ - the relative specific coke consumption; $\alpha_{n}, \alpha_{c}$ - weights of partial indices $n$ and c respectively as a part of a generalized target, reflecting the importance of performance and coke saving in the overall target structure.

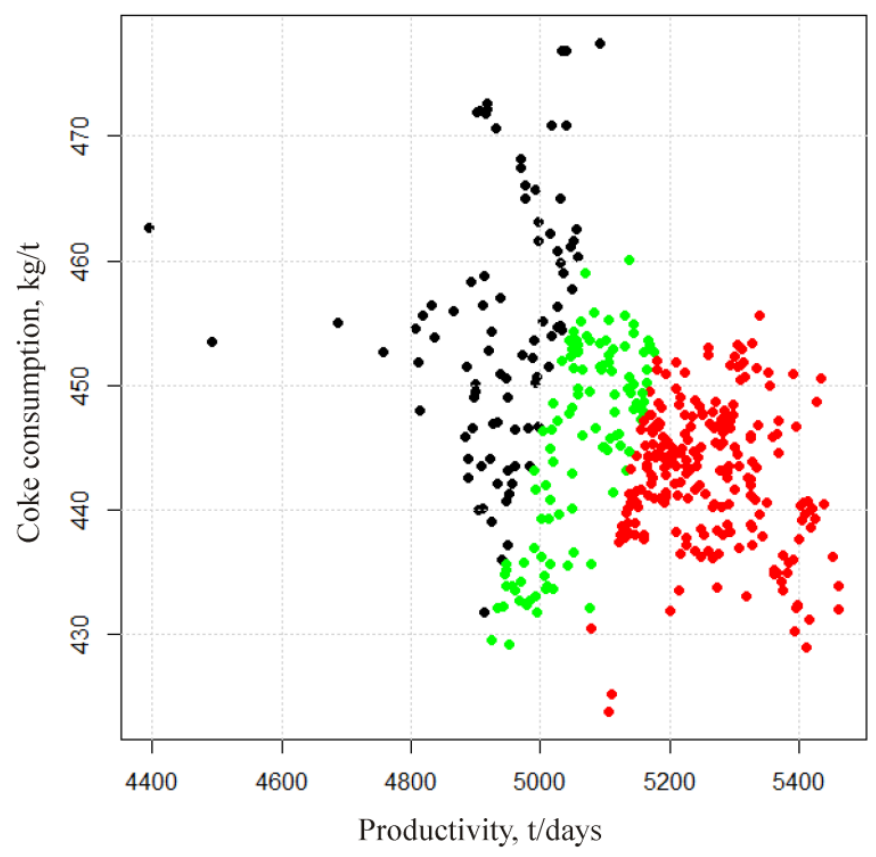

Fig. 2

Complexity of the considered effective region of operating parameters clustering task, in accordance with the division into target areas defined by specified levels of the target function (Fig. 2) caused due to is its high dimensionality. The number of operating parameters can be more than 70 . To simplify the problem solution we used the method of exact area decomposition on the two-dimensional crosssection, analytically described by second order elliptical regions [42-43].

Fig. 3 represents an example of an increased efficiency area in the coordinates of the "specific coke consumption - cast iron silicon content" including furnace thermal state constraints.

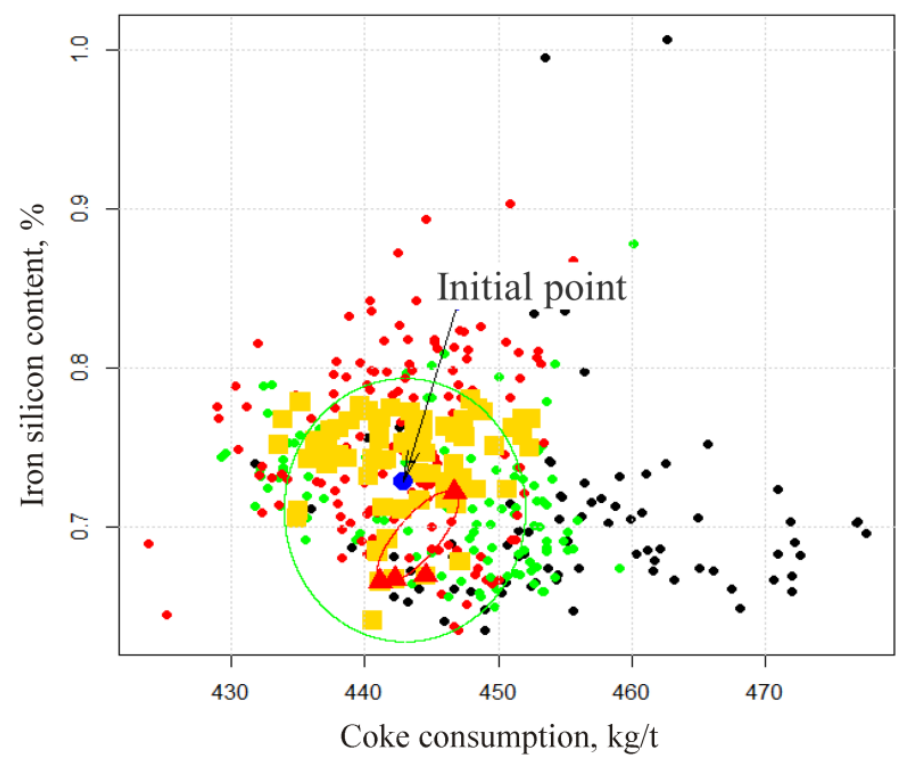

Fig. 3 
The basic task of effective solutions definition lies in selecting the BF managed parameters $\left\{x_{i}: i \in I_{m}\right\}$ under the given unmanaged parameters constraints $\left\{x_{i}: i \in I_{\text {unm }}\right\}$. In general, the exact values of uncontrollable parameters are unknown and they are defined as areas of possible values. Managed and unmanaged (defined for operational control) parameters are shown in Tables 1 and 2, respectively.

Table 1

Managed parameters

\begin{tabular}{|l|l|c|}
\hline & \multicolumn{1}{|c|}{ Parameter } & Unit \\
\hline$\left\{x_{1}: i \in I_{m}\right\}$ & The skip coke consumption (FR.+40) (abs) & $\mathrm{kg} / \mathrm{t}$ \\
\hline$\left\{x_{2}: i \in I_{m}\right\}$ & Blast moisture & $\mathrm{t} / \mathrm{M}^{3}$ \\
\hline$\left\{x_{3}: i \in I_{m}\right\}$ & Natural gas consumption & $\mathrm{m}^{3} / \mathrm{h}$ \\
\hline
\end{tabular}

Unmanaged parameters

Table 2

\begin{tabular}{|l|l|c|}
\hline & \multicolumn{1}{|c|}{ Parameter } & Unit \\
\hline$\left\{x_{4}: i \in I_{\text {unm }}\right\}$ & The hot blast oxygen content (only for fall) & $\%$ \\
\hline$\left\{x_{5}: i \in I_{\text {unm }}\right\}$ & Sokolowski pellets charge share & shares \\
\hline$\left\{x_{6}: i \in I_{\text {unm }}\right\}$ & Mickhailovski pellets charge share & shares \\
\hline$\left\{x_{7}: i \in I_{\text {unm }}\right\}$ & Lebedinski pellets charge share & shares \\
\hline$\left\{x_{8}: i \in I_{\text {unm }}\right\}$ & Kostomukshski pellets charge share & shares \\
\hline$\left\{x_{9}: i \in I_{\text {unm }}\right\}$ & Kostomukshski non-flux pellets charge share & shares \\
\hline$\left\{x_{10}: i \in I_{\text {unm }}\right\}$ & Agglomerate share & shares \\
\hline
\end{tabular}

To solve this problem a quadratic solution residual of inequalities system is formulated:

$$
\begin{aligned}
& E^{2}=0,5 \sum_{i=1}^{n} \sum_{j=1}^{n}\left(\left(f_{i j}\left(x_{i}, x_{j}\right)\right)^{+}\right)^{2}, \\
& \left(f_{i j}\left(x_{i}, x_{j}\right)\right)^{+}=\left\{\begin{array}{l}
f_{i j}\left(x_{i}, x_{j}\right), \text { if } f_{i j}\left(x_{i}, x_{j}\right)>0 ; \\
0, \text { if } f_{i j}\left(x_{i}, x_{j}\right) \leq 0,
\end{array}\right.
\end{aligned}
$$

where $f_{i j}$ - discriminant function analytically describing the effective region of the BF parameters.

The valid values of the parameters are restricted by inequalities:

$x_{i}^{\min } \leq x_{i} \leq x_{i}^{\max }, i \in I$.

Quadratic constraints residual (3):

$$
E_{x}^{2}=0,5 \sum_{i=1}^{n}\left(\left(\left(-x_{i}+x_{i}^{\min }\right)^{+}\right)^{2}+\left(\left(x_{i}-x_{i}^{\max }\right)^{+}\right)^{2}\right) \text {. }
$$

The residual of the solution (1) is based on the technological process monitoring statistics.

This statistics may be incomplete. In this case, the minimizing of solution residual problem formulation will be incorrect. We introduce the additional regularizing constraint to streamline problem formulation.

$$
E_{R}^{2}=0,5 \sum_{i=1}^{n}\left(x_{i}-x_{R i}\right)^{2}
$$

Herein $\left\{x_{R i}\right\}$ - valid values of operating parameters used for regularization; for example, the base parameters values obtained on the basis of technological calculations. Regularization usage is the central point of the approach proposed. Regularization allows generating consistent solutions based on both operating data and technological calculations.

The total residual of the inequalities solution (3) including constraints (5) is formulated as a penalty function:

$$
E_{0}^{2}=(1-\alpha) E^{2}+\lambda E_{x}^{2}+\alpha E_{R}^{2} .
$$




\section{Управление в технических системах}

The task is to find valid values of managed parameters by the criterion of minimum constraints residual (1) considering that the uncontrollable parameters within defined limits are streaming to provide the maximum of specified residual. This problem is a minimax mathematical programming problem:

$$
\min _{\left\{x_{i} \in I_{m}\right\}} \max _{\left\{x_{i} \in I_{\text {unm }}\right\}} E^{2}\left(\left\{x_{i}: i \in I\right\}\right) .
$$

In general, the solution of the problem will be implemented by the gradient descent method. In this case, the recurrence algorithm for solving the problem would be as follows:

$$
\begin{aligned}
& x_{i, k+1}=x_{i, k}-\gamma\left(\frac{\partial E^{2}}{\partial x_{i}}+\lambda \frac{\partial E_{x}^{2}}{\partial x_{i}}+\alpha \frac{\partial E_{R}^{2}}{\partial x_{i}}\right), i \in I_{m} ; \\
& x_{i, k+1}=x_{i, k}-\gamma\left(-\frac{\partial E_{\mathrm{cB}}^{2}}{\partial x_{i}}+\lambda \frac{\partial E_{x}^{2}}{\partial x_{i}}+\alpha \frac{\partial E_{R}^{2}}{\partial x_{i}}\right), i \in I_{u n m} ; \\
& \frac{\partial E^{2}}{\partial x_{i}}=f_{i i}^{+} \frac{y_{i}}{\sigma_{i}^{2}}+\sum_{\substack{j=1 \\
j \neq i}}^{n} f_{i j}^{+}\left(\frac{y_{i}}{\sigma_{i}^{2}} b_{i i}^{(11)}+\frac{y_{j}}{\sigma_{j}^{2}} b_{j i}^{(21)}\right)+\sum_{\substack{k=1 \\
k \neq i}}^{n} f_{k i}^{+}\left(\frac{y_{k}}{\sigma_{k}^{2}} b_{k i}^{(12)}+\frac{y_{i}}{\sigma_{i}^{2}} b_{i i}^{(22)}\right) ; \\
& \frac{\partial E_{x}^{2}}{\partial x_{i}}=\left(\left(-x_{i}+x_{i}^{\min }\right)^{+}+\left(x_{i}-x_{i}^{\max }\right)^{+}\right) ; \\
& \frac{\partial E_{R}^{2}}{\partial x_{i}}=x_{i}-x_{R i} .
\end{aligned}
$$

If the recurrent process converges, the result is a generalized solution of problem (7) under the given constraints.

For testing the BFp model-predictive control algorithms reporting forms are generated daily. They display BFp technological parameters of the current day, including the targets and factors of adaptive control. Based on reporting forms, a comparison is held between the actual values of factors influencing the BFp efficiency and an effective regime.

Developed algorithms based on the models produced in SCADA "PolyTER" are clarified to specify the area of high quality thermal state including the effective values of the current mode.

In addition, the approach for constructing the set of Pareto-optimal non-improvable solutions was implemented, when solving the blast furnace modes optimization problem.

The minimum coke consumption was used as the target function. Calculations were made for the following dependencies $P_{i}\left(C_{c}, W_{\text {vapor }}\right), \operatorname{Si}\left(W_{\text {vapor }}\right), M_{10}\left(W_{\text {vapor }}\right), W_{\text {vapor }}$ when setting the desired $\mathrm{BF}$ operational mode, along with thermal state constraints considering different silicon content.

Fig. 4 represents the dependence between the optimal cast iron performance and coke quality $\left(M_{10}\right)$. As we can see from the graph, cast iron performance increases while $M_{10}$ falls, therewith decreasing the $M_{10}$ productivity growth rate slows significantly. This is particularly evident when the values of $M_{10}$ are close to a 8.0 and 8.2.

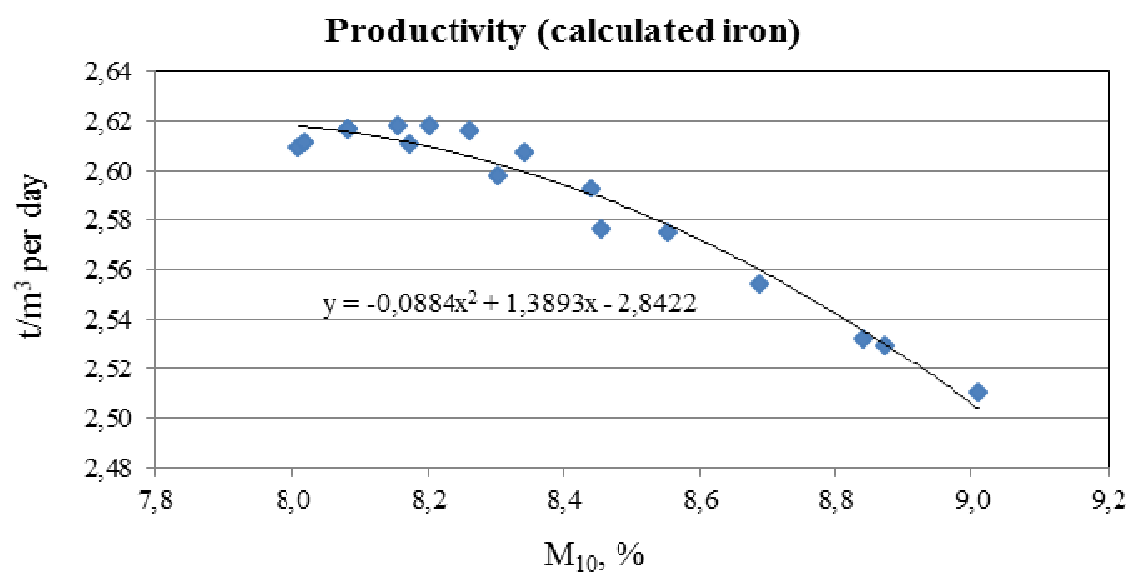

Fig. 4. Pareto region dependency between the cast iron performance andcoke quality $\left(M_{10}\right)$ 
Fig. 5 shows the obtained dependency between the optimal values of coke consumption and coke quality $\left(M_{10}\right)$. Decreasing the $M_{10}$ leads to coke consumption decrease, however the significant deceleration of coke consumption rate is not observed, when reducing $M_{10}$.

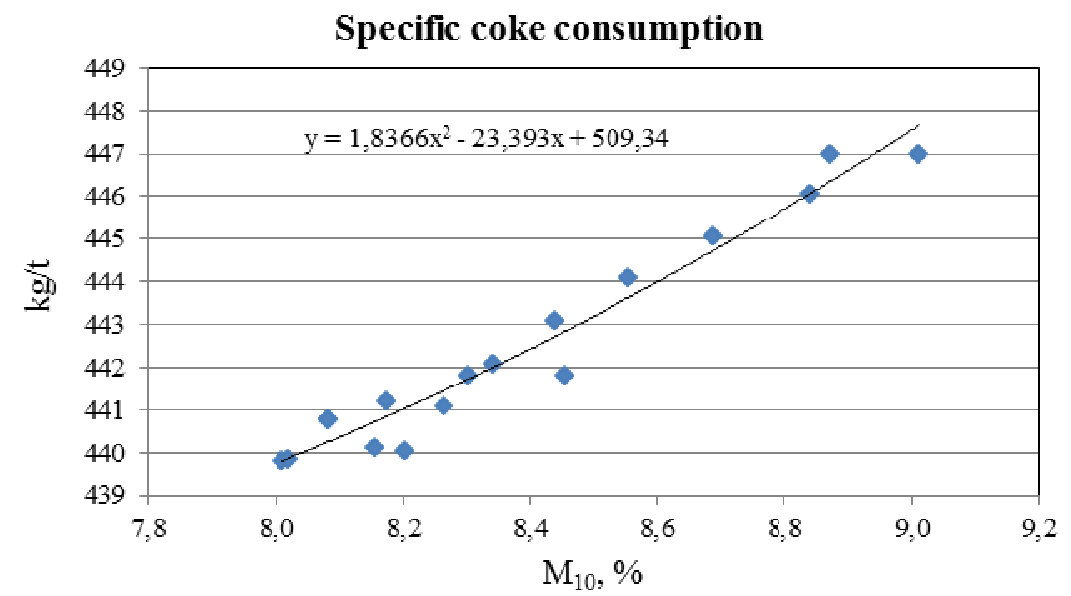

Fig. 5. Pareto region dependency between the coke consumption and coke quality $\left(M_{10}\right)$

The dependencies, shown in Fig. 4-5, were built when processing statistical information for the period from 12.04.2014 to 07.02.2016, BF № 10 OJSC “MMK" excluding the downtime periods.

\section{Operational BF real-time management}

The solution of the BF operational management problem is implemented from point of view assuming the regime parameters dynamic stabilization in the defined increased effectiveness regions. The solution to this problem is very difficult, since the blast-furnace process as a controlled object has very complex properties:

1) BFp dynamics, taking long time intervals (up to 40 hours);

2) nonlinear nonstationary characteristics;

3) distributed parameters;

4) high level of disturbances;

5) low observability of many process characteristics.

\section{Methods of operational management}

To illustrate the operational management techniques we will consider the example of cast iron silicon content regulation via the channel of specific coke consumption influence $\left(B_{\text {coke }}\right)$.

The transfer function between the cast iron silicon content $(\mathrm{Si})$ and the specific coke consumption can be represented by two sequential dynamic delays: transport and inertial.

The transport delay estimation is based on calculating correlation function between the cast iron silicon content and $B_{\text {coke }}$. Correlation function maximum defines the value of transport delay. A recurrence relation describes the inertial delay:

$\mathrm{Si}_{k}=a \mathrm{Si}_{k-1}+b B_{\text {coke } k}$,

where $a, b$ - unknown coefficients, identified on current operational data; $k$ - current time.

Identification of the $a, b$ coefficients is carried out with synchronized real time operational silicon and $B_{\text {coke }}$ data.

For silicon level regulating using the recurrent formula (8) necessary correction of the coke flow is calculated to achieve the required level of the cast iron silicon content. The required amount of silicon content is set through the previously discussed optimization problem based on the usage of efficient BF mode clusters.

For instance, Fig. 6 represents an example of silicon level regulation in an operational environment of SCADA "PolyTER".

Currently implemented operational management uses the following parameters:the cast ironsilicon content, iron temperature,titanium module, furnace shaft temperature, furnacehearth temperature.

The framework of SCADA "PolyTER" is displayed in Fig. 7. 


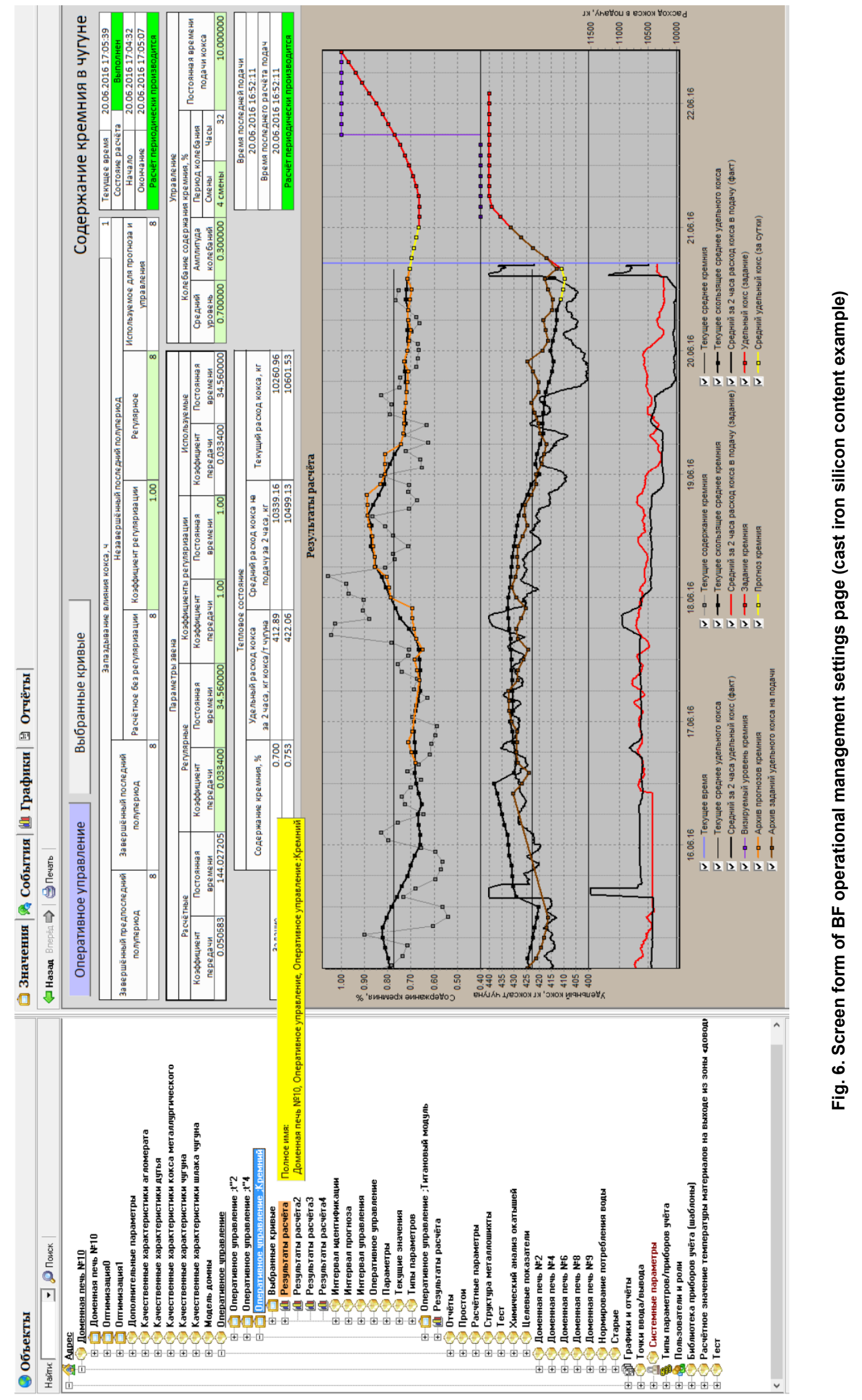


Казаринов Л.С., Шнайдер Д.А., Барбасова T.A. и др.
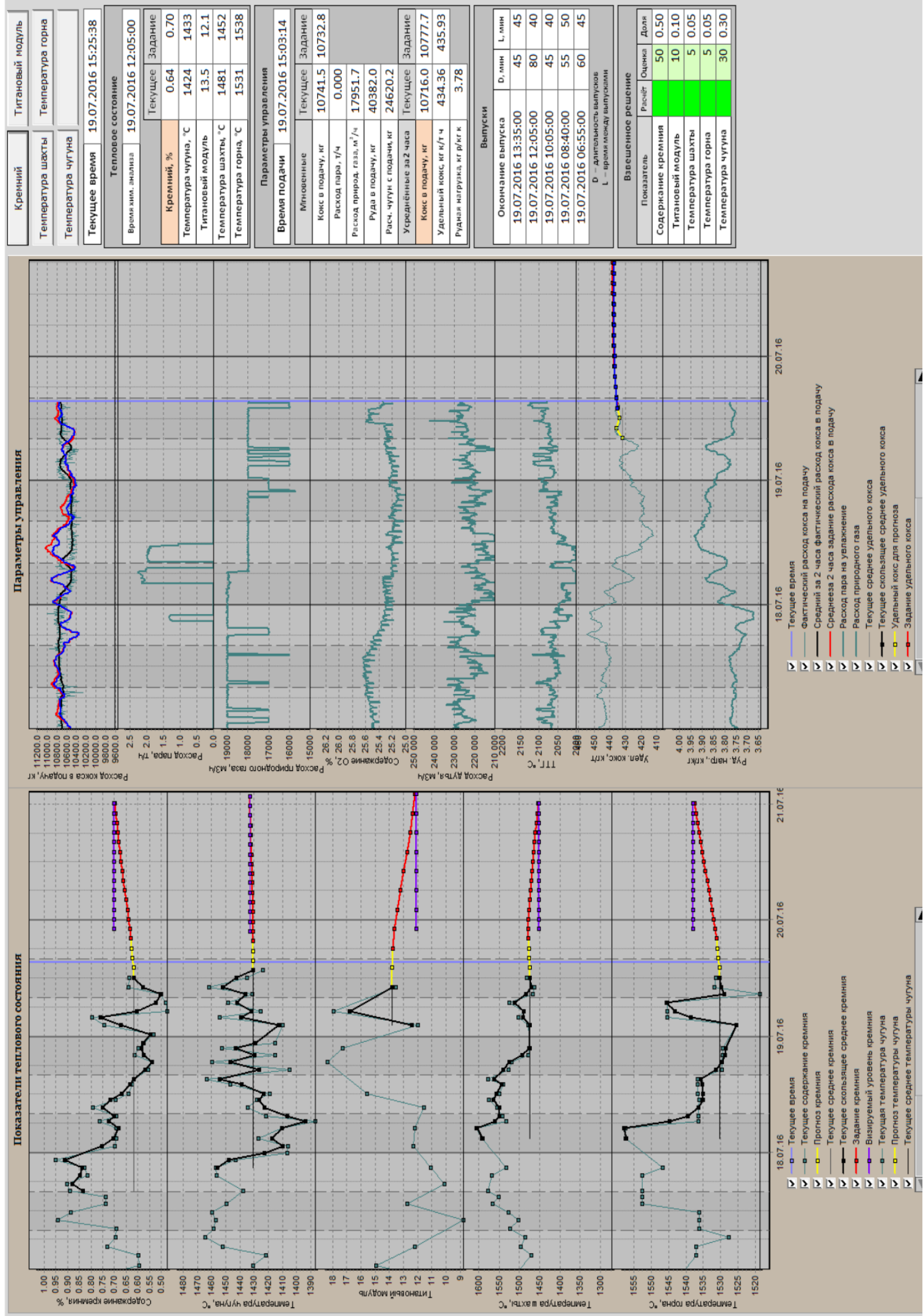


\section{Управление в технических системах}

The left part of the diagram shows the graphs of the BF thermal state indicators: cast iron silicon content, titanium module, furnace shaft temperature and furnace hearth temperature. Here each indicator matches its current value (gray-green color), filtered current values (black color), forecast values (yellow color), target values (red color) and its visual level (purple color).

The middle part of the graphs shows current values of the controlled parameters: steam consumption for humidification, natural gas consumption, oxygen content in the blast, theoretical combustion temperature, and control parameters values 2-hour averaged: coke consumption per feeding, specific coke consumption per ton of calculated iron, ore load. Moreover, system displays job graphs for the specific coke consumption:

1) defined according to the desired value of the cast iron silicon content (red line);

2) based on weighted decision (blue line). Weighted decision is using specific coke tasks defined by the required values of the $\mathrm{BF}$ thermal state indicators.

Coke consumption per feeding considering cast iron per feeding is counted through the framework charts of specific coke consumption.

\section{Conclusion}

1. To improve the blast furnace process efficiency we propose a model predictive control approach, based on clustering of blast furnace process effective parameters values regions and operational parameters stabilization within an efficient cluster using the forecast based on their dynamics.

2. We introduce method of multidimensional blast furnace effective parameters values regions decomposition using two-dimensional cross-sections and their analytical representation based on second order elliptic regions.

3. We provide the algorithmic solution for the optimal choice of blast furnace process controlled parameters with uncontrollable parameters possible variations using the multidimensional effective parameters values regions.

4. It is shown that using Pareto regions in the blast furnace process parameters coordinates, derived from the optimization problem solution, allows to assess the potential boundaries of high performance efficiency depending on the operating parameters. The obtained dependences can be used for technological calculations of the mode parameters estimating potential attainability of the effective values.

5. Blast furnace process regime parameters stabilization should be carried out based on predicting of their values using models of the dynamics. The real time dynamic models parameters identification algorithms are developed.

6. The automated blast furnace process decision support system was developed based on the methodical and algorithmic maintenance, implemented in SCADA "PolyTER".

\section{References}

1. Polyanskiy G.A., Naboka V.I., Fomenko A.P., Krutas N.V. [Mathematical Model of Control and Forecasting of the Course of Blast-furnace Process]. Fundamental and Applied Problems of Ferrous Metallurgy: Proceedings Collection, 2008, vol. 16, pp. 361-371. (in Russ.)

2. Pokhvisnev A.N., Volovik G.A. [Control of the Blast Furnace Progress Using Furnace Top Gas Analysis Questions]. Dnepropetrovsk, 1960. 198 p.

3. Pokhvisnev A.N. [Blast Furnace Process Control Based on Furnace Top Gas Content]. Metallurgy Theory and Practice, 1939, no. 8, pp. 15-19. (in Russ.)

4. Gotlib A.D., Efimenko G.G., Gimmel'farb A.A. Osnovy avtomaticheskogo regulirovaniya domennogo protsessa. V kn.: Domennyy protsess po noveyshim issledovaniyam [Blast Furnace Process Automatic Regulation Foundations. In book: The Blast-Furnace Process the Latest Researches]. Moscow, Metallurgizdat, 1963. $295 \mathrm{p}$.

5. Gimmel'farb A.A., Efimenko G.G. Avtomaticheskoe upravlenie domennym protsessom [Blast Furnace Process Automated Control]. Moscow, Metallurgiya, 1969. 378 p.

6. Tovarovskiy I.G. Domennaya plavka [Blast Furnace Melting]. Dnepropetrovsk, "POROGI" Publ., 2009. 659 p.

7. Pavlov M.A. Metallurgiya chuguna [Cast Iron Metallurgy]. Moscow, Metallurgizdat Publ., 1949. $628 \mathrm{p}$. 
8. Tovarovskiy I.G. Sovershenstvovanie $i$ optimizatsiya parametrov domennogo protsessa [Improvement and Optimization of the Blast Furnace Process Parameters]. Moscow, Metallurgiya Publ., 1987. $192 \mathrm{p}$.

9. Gotlib A.D. O "printsipe M.A. Pavlova". [About "the M. A. Pavlov Principle"]. Sbornik nauchnykh trudov akademii nauk SSSR [Collection of Scientific Works of Academy of Sciences of the USSR]. Moscow, AS USSR Publ., 1957, pp. 24-32.

10. Ramm A.N. O vliyanii intensivnosti plavki na proizvoditel'nost' domennykh pechey i otnositel'nyy raskhod koksa. Sbornik nauchnykh trudov akademii nauk SSSR [About the Melting Intensity Effect on the Blast Furnaces Productivity and Specific Coke Consumption. Collection of Scientific Works of Academy of Sciences of the USSR]. Moscow, AS USSR Publ., 1957.

11. Ramm A.N. Sovremennyy domennyy protsess [Modern Blast-Furnace Process]. Moscow, Metallurgiya Publ., 1980. 304 p.

12. Parshakov V.M., Kashirskaya T.Yu., Zabolotskikh V.A. Dvumernaya model' teploobmena $v$ domennoy pechi. Teplotekhnicheskoe obespechenie osnovnykh tekhnologicheskikh protsessov chernoy metallurgii. Sbornik trudov [Two-Dimensional Model of Heat Transfer in Blast Furnace. Thermal Engineering Maintenance of Ferrous Metallurgy Basic Technological Processes. Collection of Works]. Moscow, Metallurgiya Publ., 1988, pp. 22-25.

13. Parshakov V.M. [Increase in efficiency of use of coal-dust fuel in the blast furnace ]. Stal', 2008, no. 8, pp. 32-37. (in Russ.)

14. Parshakov V.M., Tretyak A.A., Ulanov A.P. ASU TP domennoy plavki i ee tekhnologicheskoe nasyshchenie. Domennoe proizvodstvo - XXI vek. Trudy mezhdunarodnogo kongressa domenshchikov [Blast Furnace SCADA and its Technological Abundance. Domain Production - the XXI Century. Works of the International Congress of Blast-Furnace Operators]. Moscow, Publishing house "Kodeks", 2010, pp. 391-413.

15. Vnedrenie sistemy operativnogo avtomaticheskogo opredeleniya zony plavleniya $v$ domennoy pechi v sostave ASU TP DP-2. Zaklyuchitel'nyi otchet. OOO "AKOMM" [Operational Blast Furnace Melting Zone Automatic Determination System Integrated in BF-2 SCADA Development. Final Report]. “AKOMM" Ltd. Moscow, 2015. 127 p.

16. Spirin N.A., Ipatov Yu.V., Lobanov V.I. et al. Informatsionnye sistemy v metallurgii [Information Systems in Metallurgy]. Ekaterinburg, UGTU-UPI Publ., 2001. 617 p.

17. Spirin N.A., Lavrov V.V., Parshakov S.I., Denisenko S.G. Optimizatsiya i identifikatsiya tekhnologicheskikh protsessov $v$ metallurgii [Optimization and Identification of Technological Processes in Metallurgy]. Ekaterinburg, UGTU-UPI Publ., 2006. 307 p.

18. Tovarovskiy I.G. [Standard Assessment of Influence of Parameters of Domain Melting on a Consumption of Coke and Productivity]. Stal', 2014, no. 5, pp. 4-11. (in Russ.)

19. Parsunkin B.N., Senichkin B.K., Andreev S.M., Ryabchikov M.Yu. [Increase in Productivity of the Blast Furnace by Optimization of Automatic Control of Supply of Natural Gas and Industrial Oxygen in Blasting]. Bulletin of Moscow State Technical University Named by. G. I. Nosov, 2011, no. 4, pp. 73-77. (in Russ.)

20. Onorin O.P., Spirin N.A., Terent'ev V.L., Gileva L.Yu., Rybolovlev V.Yu et al. Komp'yuternye metody modelirovaniya domennogo protsessa [Computer Methods of the Blast Furnace Process Simulation. Ekaterinburg, UGTU-UPI Publ., 2005. 301 p.

21. Zherebin B.N. Praktika vedeniya domennoy pechi [The Blast Furnace Control Practice]. Moscow, Metallurgiya Publ., 1980. 248 p.

22. Tovarovskiy I.G., E.I. Raykh, K.K. Shkodin et al. Primenenie matematicheskikh metodov i EVM dlya analiza i upravleniya domennym protsessom [Mathematical Methods and Computers Application for the Blast Furnace Process Analysis and Control]. Moscow, Metallurgiya Publ., 1978. 204 p.

23. Avdeev V.P., Danielyan T.M., Belousov P.G. Identifikatsiya promyshlennykh ob"ektov s uchetom nestatsionarnostey $i$ obratnykh svyazey [Industrial Facilities Identification with Consideration of Nonstationaries and Feedback]. Novokuznetsk, SibMI Publ, 1984. 88 p.

24. Suchkov A.V., Lisienko V.G., Suchkov V.A. Soverenstvovanie upravleniya mnogomernymi tekhnologicheskim ob"ektom na primere domennoy pechi [Improvement of Multidimensional Technological Object Control on Blast Furnace Example]. Ekatrinburg, UrFU Publ., 2012. 126 p. 


\section{Управление в технических системах}

25. Dmitriev A.N., Shumakov N.S., Leont'ev L.I., Onorin O.P. Osnovy teorii i tekhnologii domennoy plavki [Fundamentals of Blast Furnace Theory and Technology]. Ekaterinburg, UrO RAN Publ., 2005. $545 \mathrm{p}$.

26. Lisienko V.G. Sovershenstvovanie i povyshenie effektivnosti energotekhnologiy i proizvodstv [Improving and Increasing the Efficiency of Energy Technologies and Production]. Ekaterinburg, UrFU Publ., 2013. 592 p.

27. Blast Furnace Phenomena and Modelling / Ed. By Yasuo Omori. Elsevier applied science. London and New York, 1987. $631 \mathrm{p}$.

28. Sasaki M., Ono K., Suzuki A. Formation and Melt-down of Softening-Melting Zone in Blast Furnace. Trans. Of the Iron and Steel Inst. Jap., 1977, vol.17, no. 7, pp. 391-400.

29. Burgess J.M., Jenkins D.R., Hockings K.L. Analysis of Blast Furnace Pressure Tappings, using a Cohesive-zone Gas-distribution Model. Ironmakinf and Steelmaking, 1984, vol. 11, no. 5, pp. 253-261.

30. Togino Y., Sugata M., Yamaguchi K. Estimation of Lower Limit of Fuel Rate in Blast Furnace by Mathematical Model. Trans. of the Iron and Steel Inst. Jap., 1980, vol. 20, no. 9, pp. 639-645.

31. Yagi J., Takeda K., Omori Y. et al. Two-dimensional Simulation on the Gas Flow and Heat Transfer in the Blast Furnace. Trans. of the Iron and Steel Inst. Jap., 1983, vol. 22, no. 11, pp. 884-892.

32. Fukushima T., Fukyama T., Yamada Y. et al. Development of Measuring Technique for Coheszive Zone and its Application Process in Ohgishima Blast Furnace. Trans. of the Iron and Steel Inst. Jap., 1982, vol. 22, no. 10, pp. 807-810.

33. Sugiama T., Yagi J.,Omori Y. A Theoretical Analisis on Gas Flow and Heat Transfer in Packed Beds with Fused and Unfused Layers. Tetsu-to-Hagane. Journal of the Iron and Steel Inst. Jap., 1978, vol. 64 , no. 12, pp. 1676-1684.

34. Kule J. Blast Furnace Model Development and Application in the British Steel Corporation. Proc. Conf., Univ. Surrey. Sept. 11th-13th. 1979. London, 1980, pp. 403-415.

35. Yagi J. Mathematical Models of the Blast Furnace Process. Tetsu-to-Hagane, 1983, no. 10, pp. 1242-1249.

36. Kumar S.A., Suresh N. Production and Operations Management. New Age International (P) Ltd., 2009. 284 p.

37. Modrak V., Pandian R.S. Operations Management Research and Cellular Manufacturing Systems: Innovative Methods and Approaches. IGI Global Snippet, 2011. 456 p.

38. Gobetto M. Operations Management in Automotive Industries: From Industrial Strategies to Production Resources Management, Through the Industrialization Process. Springer Science + Business Media Dordrecht, 2014, XXII. 245 p. DOI: 10.1007/978-94-007-7593

39. Kwakernaak H., Tijssen P., Strijbos R.C.W. Optimal Operation of Blast Furnace Stoves. Automatics, 1970, vol. 6, no. 1, pp. 33-40.

40. Jeffreson C.P. Feedforward Control of Blast Furnace Stoves. Automatics, 1979, vol. 15, no. 2, pp. 149-159.

41. Garry A. Labossiere, Peter L. Lee Model-based Control of a Blast Furnace Stove rig. Journal of Process Control, 1991, vol. 1, no. 4, pp. 217-227.

42. Kazarinov L.S., Barbasova T.A. Oblong Ellipsoid Method in Process Efficiency Control. International Conference on Mechanical Engineering, Automation and Control Systems (MEACS) Tomsk, Russia, 2015, pp. 1-5. DOI: 10.1109/MEACS.2015.7414875

43. Kazarinov L.S., Barbasova T.A. Identification Method of Blast-Furnace Process Parameters. International Conference for young scientists "High Technology: Research and Applications 2015 (HTRA 2015)", Key Engineering Materials, 2016, vol. 685, pp. 137-141. DOI: 10.4028/www.scientific.net/KEM.685.137

Received 10 October 2016 


\title{
АВТОМАТИЗАЦИЯ ОПЕРАТИВНОГО УПРАВЛЕНИЯ ДОМЕННЫМ ПРОЦЕССОМ С ИСПОЛЬЗОВАНИЕМ МОДЕЛЬНО-УПРЕЖДАЮЩЕГО ПОДХОДА
}

\author{
Л.С. Казаринов ${ }^{1}$, Д.А. Шнайдер ${ }^{1}$, Т.А. Барбасова ${ }^{1}$, \\ А.А. Басалаев ${ }^{1}$, О.В. Колесникова ${ }^{1}$, В.А. Липатников ${ }^{2}$ \\ ${ }^{1}$ Южно-Уральский государственный университет, г. Челябинск, \\ ${ }^{2} \mathrm{OAO}$ «Магнитогорский металлургический комбинат», г. Магнитогорск
}

\begin{abstract}
Рассматривается задача автоматизации оперативного управления доменным процессом с использованием методов, основанных на моделировании и выработке упреждающих решений в реальном времени on-line с объектом управления. Характерными особенностями создаваемой системы оперативного управления являются:

- использование программных средств интеллектуального анализа данных эксплуатации для выявления эффективных областей значений режимных параметров печи;

- наличие программы идентификации в реальном времени текущих параметров зоны когезии доменного процесса для коррекции оперативного управления;

- прогнозирование динамики изменения индикаторов теплового состояния печи при изменениях параметров дутья и загрузки шихтовых материалов.

В результате применения указанных программных средств достигается выведение режимных параметров доменного процесса в эффективную область значений повышенной производительности и снижение потребления кокса при значительных изменениях исходных параметров шихты, которые обусловлены использованием шихтовых материалов от разных поставщиков. При этом прогнозирование динамики режимных параметров позволяет мастеру стабилизировать доменный процесс в эффективной области их значений.

Система реализуется в рамках совместной разработки Южно-Уральского государственного университета (национального исследовательского университета) (Челябинск), ООО НПП «Политех-Автоматика» (Челябинск) и ООО «АКОММ» (Москва).

Ключевые слова: доменный прочесс, модельно-упреждающее управление.
\end{abstract}

\section{Лuтература}

1. Математическая модель контроля и прогнозирования хода доменного процесса / Г.А. Полянский, В.И. Набока, А.П. Фоменко, Н.В. Крутас // Фундаментальные и прикладные проблемы черной металлургии: сб. науч. тр. - Днепропетровск, 2008. - Вып. 16. - С. 361-371.

2. Похвиснев, А.Н. К вопросу о регулировании хода доменной печи по анализу колошникового газа / А.Н. Похвиснев, Г.А. Воловик // Научные исследования в помощь доменному производству: сб. тр. - Днепропетровск: Днепропетров. кн. изд-во, 1960. - 198 с.

3. Похвиснев, А.Н. Управление доменным процессом по изменению состава колошникового газа / А.Н. Похвиснев // Теория и практика металлургии. - 1939. - № 8. - С. 15-19.

4. Готлиб, А.Д. Основы автоматического регулирования доменного процесса / А.Д. Готлиб, Г.Г. Ефименко, А.А. Гиммельфарб // Доменный проиесс по новейшим исследованиям. - М.: Металлургиздат, 1963. - 295 с.

5. Гиммельфарб, А.А. Автоматическое управление доменным проиессом / А.А. Гиммельфарб, Г.Г. Ефименко. - М.: Металлургия, 1969. - 378 с.

6. Товаровский, И.Г. Доменная плавка: моногр. / И.Г. Товаровский. - 2-е изд., уточнен., Дніпропетровськ: ПОРОГИ, 2009. - 659 с.

7. Павлов, М.А. Металлургия чугуна. Ч.2: Доменный проиесс / М.А. Павлов. - Изд. шестое. М.: Металлургиздат, 1949. - 628 с.

8. Товаровский, И.Г. Совершенствование и оптимизация параметров доменного прочесса / И.Г. Товаровский. - М.: Металлургия, 1987. - 192 с.

9. Готлиб, А.Д. О «принщипе М.А. Павлова» / А.Д. Готлиб // Исследование доменного прочесса: сб. тр. - М.: Изд-во АН СССР, 1957. - С. 24-32. 


\section{Управление в технических системах}

10. Рамм, А.Н. О влиянии интенсивности плавки на производительность доменных печей и относительный расход кокса / А.Н. Рамм // Исследование доменного процесса: сб. науч. тр. / АН СССР. - М.: Изд-во АН СССР, 1957. - С. 85-87.

11. Рамм, А.Н. Современный доменный проиесс / А.Н. Рамм. - М.: Металлургия, 1980. - 304 с.

12. Паршаков, В.М. Двумерная модель теплообмена в доменной печи / В.М. Паршаков, Т.Ю. Каширская, В.А. Заболотских // Теплотехническое обеспечение основных технологических прочессов чёрной металлургии: сб. тр. - М.: Металлургия, 1988. - С. 22-25.

13. Паршаков, В.М. Повышение эффективности использования пылеугольного топлива в доменной печи / В.М. Паршаков // Сталь. - 2005. - № 8. - С. 32-37.

14. Паршаков, В.М. АСУ ТП доменной плавки и её технологическое насыщение / В.М. Паршаков, А.А. Третяк, А.П. Уланов. // Доменное производство - ХХІ век. Труды Международного конгресса доменщиков. - М.: Издат. дом «Кодекс», 2010. - С. 391-413.

15. Внедрение системы оперативного автоматического определения зоны плавления в доменной печи в составе АСУ ТП ДП-2: заключительный отчет / ООО «АКОММ»; рук. В.М. Паршаков. - М., 2015. - 137 c.

16. Информационные системы в металлургии / Н.А. Спирин, Ю.В. Ипатов, В.И. Лобанов и др.; под ред. Н.А. Спирина. - Екатеринбург: УГТУ-УПИ, 2001. - 617 с.

17. Оптимизация и идентификаџия технологических процессов в металлургии / Н.A. Спирин, В.В. Лавров, С.И. Паршаков, С.Г. Денисенко; под ред. Н.А. Спирина. - Екатеринбург: УГТУУПИ, 2006. - 307 с.

18. Товаровский, И.Г. Нормативная оценка влияния параметров доменной плавки на расход кокса и производительность / И.Г. Товаровский // Сталь. - 2014. - № 5. - C. 4-11.

19. Повышение производительности доменной печи при оптимизации автоматического управления подачей природного газа и технического кислорода в дутье / Б.Н. Парсункин, Б.К. Сеничкин, С.М. Андреев, М.Ю. Рябчиков // Вестник МГТУ им. Г.И. Носова. - 2011. - № 4. - С. $73-77$.

20. Компьютерные методы моделирования доменного процесса / О.П. Онорин, Н.А. Спирин, В.Л. Терентьев и др.; под ред. Н.А. Спирина. - Екатеринбург: УГТУ-УПИ, 2005. - 301 c.

21. Жеребин, Б.Н. Практика ведения доменной печи / Б.Н. Жеребин. - М.: Металлургия, 1980. -248 c.

22. Применение математических методов и ЭВМ для анализа и управления доменным процессом / И.Г. Товаровский, Е.И. Райх, К.К. Шкодин и др. - М.: Металлургия, 1978. - 204 с.

23. Авдеев, В.П. Идентификаџия промышленных объектов с учетом нестационарностей и обратных связей / В.П. Авдеев, Т.М. Даниелян, П.Г. Белоусов. - Новокузнеик: СибМИ, 1984. - 88 с.

24. Сучков, А.В. Совериенствованиеуправлениямногомерными технологическим объектом на примере доменной печи: моногр. / А.В. Сучков, В.Г.Лисиенко, В.А. Сучков.-Екатринбург: УрФУ, 2012.-126 с.

25. Основы теории и технологии доменной плавки / А.Н. Дмитриев, Н.С. Шумаков, Л.И. Леонтьев, О.П. Онорин. - Екатеринбург: УрО РАН, 2005. - 545 с.

26. Лисиенко, В.Г. Совериенствование и повышение эффективности энерготехнологий и производств. Т. 2. Кн.1: Новые способы, модельные и экспериментальные исследования: моногр. / В.Г. Лисиенко. - Екатеринбург: УрФУ, 2013. - 592 с.

27. Blast Furnace Phenomena and Modelling / Ed. By Yasuo Omori. - London and New York: Elsevier applied science, $1987 .-631 \mathrm{p}$.

28. Sasaki, M. Formation and Melt-down of Softening-Melting Zone in Blast Furnace / M. Sasaki, K. Ono, A. Suzuki // Trans. of the Iron and Steel Inst. Jap. - 1977. - Vol.17, no. 7. - P. 391-400.

29. Burgess, J.M. Analysis of Blast Furnace Pressure Tappings, using a Cohesive-zone Gasdistribution Model / J.M. Burgess, D.R. Jenkins, K.L. Hockings // Ironmaking and Steelmaking. - 1984. Vol. 11, no. 5. - P. 253-261.

30. Togino, Y. Estimation of Lower Limit of Fuel Rate in Blast Furnace by Mathematical Model / Y. Togino, M. Sugata, K. Yamaguchi // Trans. of the Iron and Steel Inst. Jap. - 1980. - Vol. 20, no. 9. - P. 639-645.

31. Two-dimensional Simulation on the Gas Flow and Heat Transfer in the Blast Furnace / J. Yagi, K. Takeda, Y. Omori et al. // Trans. of the Iron and Steel Inst. Jap. - 1983. - Vol. 22, no. 11. - P. 884-892.

32. Development of Measuring Technique for Coheszive Zone and its Application Process in Ohgishima Blast Furnace / T. Fukushima, T. Fukyama, Y. Yamada et al. // Trans. of the Iron and Steel Inst. Jap. - 1982. - Vol. 22, no. 10. - P. 807-810. 
33. Sugiama, T. A Theoretical Analisis on Gas Flow and Heat Transfer in Packed Beds with Fused and Unfused Layers / T. Sugiama, J. Yagi, Y. Omori // Tetsu-to-Hagane. Jorn. of the Iron and Steel Inst. Jap. - 1978. - Vol. 64, no. 12. - P. 1676-1684.

34. Kule, J. Blast Furnace Model Development and Application in the British Steel Corporation / J. Kule // Proc. Conf., Univ. Surrey. Sept. 11th-13th. 1979. - London, 1980. - P. 403-415.

35. Yagi, J. Mathematical Models of the Blast Furnace Process / J. Yagi // Tetsu-to-Hagane. 1983. - No. 10. - P. 1242-1249.

36. Kumar, S.A. Production and Operations Management / S.A. Kumar, N. Suresh. - New Age International (P) Ltd., 2009. - 284 p.

37. Modrak, V. Operations Management Research and Cellular Manufacturing Systems: Innovative Methods and Approaches / V. Modrak, R.S. Pandian. - IGI Global Snippet, 2011. - 456 p.

38. Gobetto M. Operations management in automotive industries: from industrial strategies to production resources management, through the industrialization process and supply chain to pursue value creation. - Springer Science + Business Media Dordrecht, 2014 - XXII. - 245 p. DOI: 10.1007/978-94-007-7593

39. Kwakernaak, H. Optimal Operation of Blast Furnace Stoves / H. Kwakernaak, P. Tijssen, R.C.W. Strijbos // Automatica. - 1970. - Vol. 6, no. 1. - P. 33-40.

40. Jeffreson C.P. Feedforward Control of Blast Furnace Stoves / C.P. Jeffreson // Automatica. 1979. - Vol. 15, no. 2. - P. 149-159.

41. Labossiere, G.A. Model-based Control of a Blast Furnace Stove Rig / Garry A. Labossiere, Peter L. Lee // Journal of Process Control. - 1991. - Vol. 1, no. 4. - P. 217-227.

42. Kazarinov, L.S. Oblong Ellipsoid Method in Process Efficiency Control / L.S. Kazarinov, T.A. Barbasova // International Conference on Mechanical Engineering, Automation and Control Systems (MEACS). - Tomsk, Russia, 2015. - P. 1-5. DOI: 10.1109/MEACS.2015.7414875

43. Kazarinov, L.S. Identification Method of Blast-Furnace Process Parameters / L.S. Kazarinov, T.A. Barbasova // International Conference for young scientists "High Technology: Research and Applications 2015 (HTRA 2015)", Key Engineering Materials. - 2016. - Vol. 685. - P. 137-141. DOI: 10.4028/www.scientific.net/KEM.685.137

Казаринов Лев Сергеевич, д-р техн. наук, профессор кафедры автоматики и управления, Южно-Уральский государственный университет, г. Челябинск; kazarinovls@susu.ru.

Шнайдер Дмитрий Александрович, д-р техн. наук, профессор кафедры автоматики и управления, Южно-Уральский государственный университет, г. Челябинск; shnaiderda@susu.ru.

Барбасова Татьяна Александровна, канд. техн. наук, доцент кафедры автоматики и управления, Южно-Уральский государственный университет, г. Челябинск; barbasovata@susu.ru.

Басалаев Александр Анатольевич, ассистент кафедры автоматики и управления, ЮжноУральский государственный университет, г. Челябинск; basalaevaa@susu.ru.

Колесникова Ольга Валерьевна, канд. техн. наук, доцент кафедры автоматики и управления, Южно-Уральский государственный университет, г. Челябинск; kolesnikovaov@susu.ru.

Липатников Андрей Владимирович, ведущий специалист Центра системно-аналитических исследований, ОАО «Магнитогорский металлургический комбинат», г. Магнитогорск; 1lipass@mail.ru.

Поступила в редакцию 10 октября 2016 г.

\section{ОБРАЗЕЦ ЦИТИРОВАНИЯ}

A Model Predictive Approach to Blast Furnace Operational Management Automation / L.S. Kazarinov, D.A. Shnayder, T.A. Barbasova et al. // Вестник ЮУрГУ. Серия «Компьютерные технологии, управление, радиоэлектроника». - 2016. - Т. 16, № 4. - С. 36-49. DOI: $10.14529 / \operatorname{ctcr} 160405$

\section{FOR CITATION}

Kazarinov L.S., Shnayder D.A., Barbasova T.A., Basalaev A.A., Kolesnikova O.V., Lipatnikov A.V. A Model Predictive Approach to Blast Furnace Operational Management Automation. Bulletin of the South Ural State University. Ser. Computer Technologies, Automatic Control, Radio Electronics, 2016, vol. 16, no. 4, pp. 36-49. DOI: $10.14529 /$ ctcr160405 